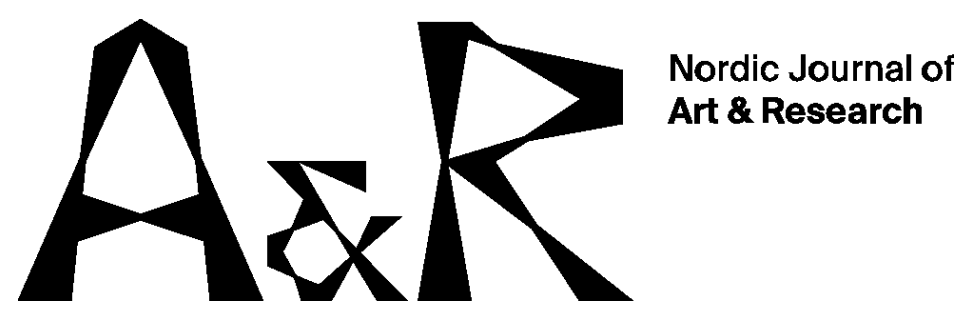

ISSN: $1893-2479$

www.artandresearch.info

\title{
I kjønneste orden?
}

\section{Kvalitet og betydningen av kjønn i vurdering av professor- og dosentkompetanse i kunstfagene}

\author{
Hilde Synnøve Blix ${ }^{1}$, Lilli Mittner², Rikke Gürgens Gjærum³ \\ UiT - Norges arktiske universitet
}

\begin{abstract}
Sammendrag: Denne artikkelen har som mål å bidra til diskusjoner om begrepet kvalitet slik det framkommer i bedømmelsesprosesser ved professor- og dosentopprykk, gjennom å utforske hvorvidt og hvordan kjønn har betydning for måten kvalitet vurderes og kommer til uttrykk på i slike prosesser. Studien er en analyse av dybdeintervjuer med fem erfarne komitémedlemmer i kunstutdanningsfeltet $\mathrm{i}$ Norge. Vår analyse av datamaterialet ledet til tre sentrale diskurser: kvalitetsdiskursen, kjønnsdiskursen og elitediskursen. Studien viser at komitémedlemmene operasjonaliserer sin kvalitetsforståe/se med utgangspunkt i markører som arena, publikumstype, nyskaping, samarbeidsrelasjoner og egenart. Samtidig framhever informantene at kvalitetskriteriene i forskriften er for uklare. Disse vage kriteriene for opprykk, sammen med et dominerende elitistisk kunstsyn i kunstutdanningsfeltet, fører ifølge informantene til at de som allerede har definisjonsmakt fortsetter å forvalte rådende definisjoner av kvalitet. Informantene forteller at det er de spesifikt kunstfaglige kriteriene som er vanskeligst å konkretisere. Komitémedlemmene mener at kjønn har en betydning både for måten en bedømmer kvalitet på og måten en fremskriver kvalitet på i egen søknad. Studien viser et eksplisitt behov for tydelig artikulerte kriterier i forskriften for hva som konstituerer kvalitet $\mathrm{i}$ utøvende kunst på professor-/dosentnivå i Norge.
\end{abstract}

Emneord: Kvalitet, kjønn, vurdering, elite, makt, kompetanseopprykk, kunstfag og diskurs

\footnotetext{
${ }^{1}$ Professor ved Musikkonservatoriet, UiT - Norges arktiske universitet. E-mail: hilde.blix@uit.no

${ }^{2}$ Postdoktor ved Senter for kvinne- og kjønnsforskning, UiT - Norges arktiske universitet. E-mail: lilli.mittner@uit.no

${ }^{3}$ Professor ved institutt for vernepleie, UiT - Norges arktiske universitet, rikke.g.gjarum@uit.no
} 


\section{Innledning}

De siste 25 årene er det utdannet omtrent like mange kvinnelige som mannlige kunstnere ${ }^{4}$ Norge. Likevel inntar menn fremdeles de fleste ledende posisjonene på kunstarenaer både innenfor og utenfor akademia, og den manglende kjønnsbalansen på kunstfeltet viser seg å være gjenstridig (Abelsen, 2009; Gjærum et al., 2015). I 2017 var det eksempelvis 32\% kvinner på professor-/dosentnivå ved kunstutdanningene i Norge, og i musikkfagene ved universiteter og vitenskapelige høgskoler var kvinneandelen spesielt lav med kun 21\% kvinnelige professorer/dosenter (Gunnes \& Olsen, 2018).

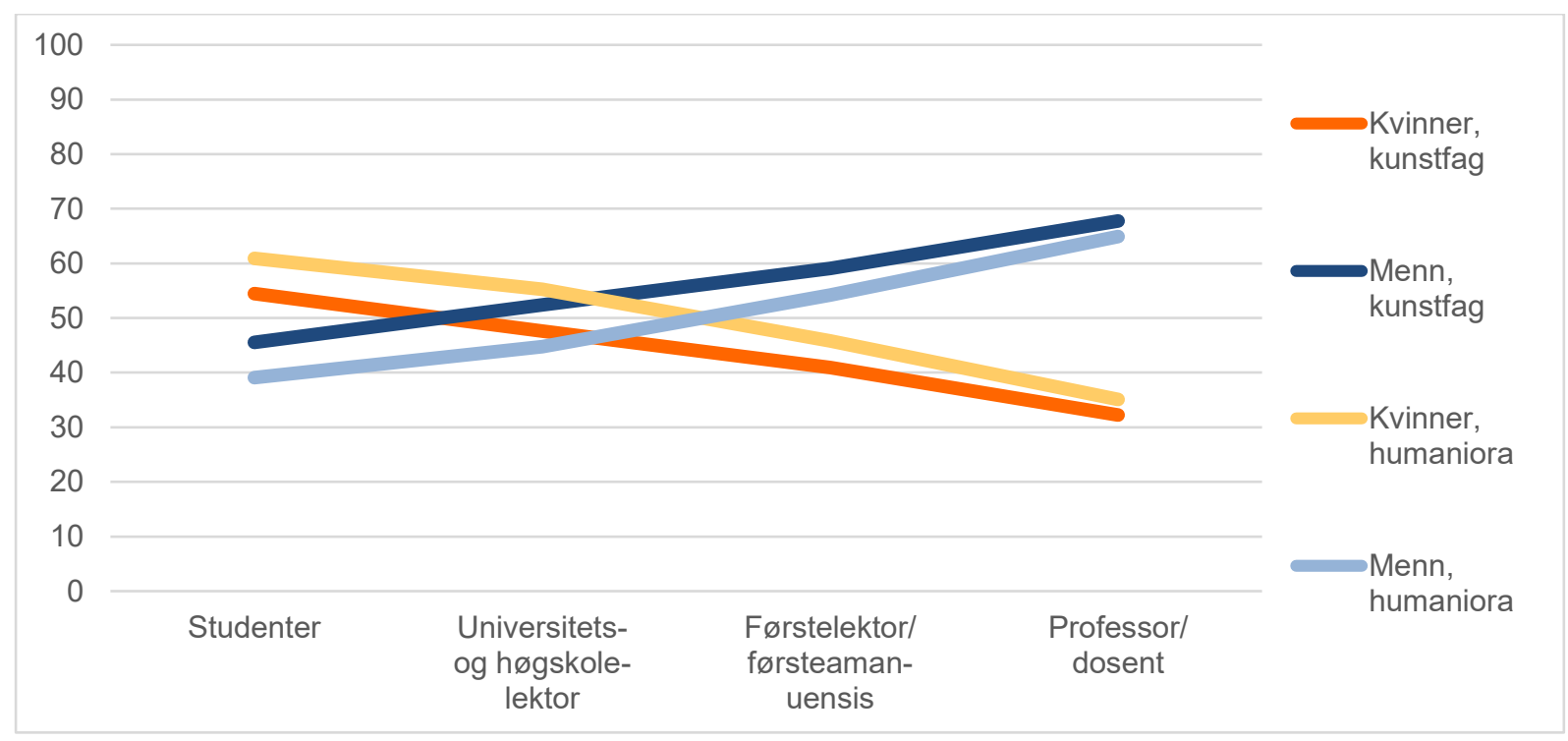

Karrierestigen for kvinner og menn innenfor kunstfagene og humaniora totalt i 2017 (Gunnes \& Olsen, 2018)

Kritikk for manglende kjønnsbalanse ved institusjoner som NRK, universiteter, festivaler og gallerier blir ofte avfeid med at en ikke tenker på kjønn når en velger kunstnere, men tar valg utelukkende på bakgrunn av kvalitet. ${ }^{5}$ I alle kunstformer er kvalitetsvurderinger en betydningsfull del av kunstutøverens liv og virke. Utøvende kunstnere gjennomgår kvalitetsvurderinger både i forbindelse med tildeling av midler, tilgang på visningssteder, utvelgelse til deltakelse på festivaler og biennaler samt ved tildeling av stipender eller stillinger.

I universitets- og høgskolesektoren vurderes utøvende kunstnere både når de konkurrerer om stillinger og når de søker opprykk til stillingskategorier som førsteamanuensis/førstelektor eller professor/dosent. Kvalitetsvurderinger på kunstfeltet er til kontinuerlig debatt (Biggs \& Karlsson, 2010; Mortensen, 2015), og når kvalitet som fenomen diskuteres, aktualiseres aspekter som definisjonsmakt og kunnskap, men også forfordeling og partiskhet. Vi ønsket å undersøke hvordan vurdering av toppkompetanse foregår i akademia, og valgte å avgrense denne studien til vurderingene som gjøres i forbindelse med søknader om opprykk i kunstneriske fag (musikk, drama/teater og visuelle kunst) gjennom å intervjue erfarne komitémedlemmer av bedømmelseskomiteer. Årlig gjennomføres det i Norge et tyvetalls komitévurderinger av kunstnere som søker slike opprykk. Hver søker blir vurdert av tre fagpersoner som selv er professorer/dosenter i det respektive kunstfag.

\footnotetext{
${ }^{4}$ Begrepet kunstner brukes i denne artikkelen om profesjonelle utøvere av alle typer kunst; visuell kunst, musikk, teater, film etc.

${ }^{5}$ Eksempelvis ser vi denne debatten jevnlig i musikkmagasinet Ballade: http://www.ballade.no/sak/kvalitet-ikke$\underline{\text { kjonn/ }}$
} 
Studien har hatt som mål å bidra til diskusjoner rundt kvalitetsbegrepet, og å utforske hvorvidt kjønn har betydning for måten kvalitet vurderes og kommer til uttrykk. Vi har i studien reist to forskningsspørsmål:

1. Hvordan blir kvalitet forstått og forvaltet i vurdering av professor-/dosentkompetanse i høyere kunstutdanninger?

2. Hvorvidt og på hvilke måter mener komitémedlemmene at kjønn har betydning for måten kvalitet vurderes- og hvordan kommer dette til uttrykk?

\section{Bakgrunn og relevans}

Det kunstfaglige fakultet ved UiT - Norges arktiske universitet har de siste årene hatt spesielt fokus på kunstfeltets skjeve kjønnsfordeling, særlig i toppstillinger i akademia. Våren 2015 igangsatte fakultetet prosjektet Kjønn og skjønn i kunstfagene - «nye» karrierebarrierer for kvinner? Prosjektet ble finansiert av Norges forskningsråd og var en del av forskningsrådets nasjonale BALANSE-program, som har som mål å bidra til å «... utvikle virkemidler og strategier for å bedre kjønnsbalanse på seniornivå i akademia»». ${ }^{6}$ Studien er en del av prosjektets målsetting gjennom å utvikle ny kunnskap om hva en legger i kunstnerisk kvalitet på høyt nivå i fagene musikk, drama/teater og visuell kunst. Et viktig spørsmål i prosjektet har vært hvilken betydning utdanningsinstitusjonenes forvaltning og operasjonalisering av kvalitetsbegrepet har for kvinners karrieremuligheter i kunstutdanningene i UHsektoren.

Vurderinger i tilsettings- og opprykkprosesser er for kunstneriske stillinger basert på andre kriterier enn i mer tradisjonelle vitenskapelige stillinger. Kriterier for opprykk til professor i akademiske fag er: «Vitenskapelig nivå i samsvar med etablerte internasjonale eller nasjonale standarder». Kriterier for opprykk til stilling som professor i utøvende kunstfag lyder: «Omfattende kunstnerisk virksomhet på høyeste nivå etter internasjonal standard og relevant bredde og fordypning i faget eller disiplinen på høyeste nivå». ${ }^{7}$ Kvalitetskriteriene i tradisjonelle akademiske fag er på mange måter klarere og mer forutsigbare enn i kunstfagene, fordi en med «etablerte standarder» henviser til fagfellevurderte artikler som følger relativt etablerte normer. ${ }^{8}$ I mange sammenhenger ser en at konkretisering av hva kunstneriske kvaliteter er, oppfattes som vanskelig å uttrykke verbalt, noe som ofte fører til at faktorer som anerkjennelse, ressurstilgang og renommé brukes som kvalitetsindikatorer (Stavrum, 2014).

\section{Kunnskap på feltet}

Diskusjoner rundt kvalitetsbegrepet finnes i alle fagfelt, men er kanskje særlig vektlagt i utøvende kunstfag. Både scenekunst, litteratur, musikk, arkitektur, dans og visuell kunst har sine fagspesifikke tradisjoner og utfordringer med å definere hva som til enhver tid konstituerer kvalitet (Eliassen \& Prytz, 2016; Lund et al., 2001). Betydningen av kjønn i denne sammenheng understrekes i rapporter som for eksempel På väg mot jämnställd scenkonst (Nyamko \& Twengström, 2009) og det svenske Vetenskapsrådets studie Jämnställdhetsobservationer $i$ ett urval av vetenskapsrådets beredningsgrupper 2012 (Ahlqvist et al., 2013) som viser at kategorien kjønn, definert som et

\footnotetext{
${ }^{6}$ https://www.forskningsradet.no/prognettbalanse/Nyheter/Her_er_UiBs_BALANSEprosjekt/1254024810142?WT.mc id=nyhetsbrev-balanse

${ }^{7}$ Forskrift om ansettelse og opprykk i undervisnings- og forskerstillinger $\S 1-2$ (2)

${ }^{8}$ https://dbh.nsd.uib.no/publiseringskanaler/OmKriterier
} 
performativt fenomen (Butler, 1990), er en viktig, og utslagsgivende, faktor i både evalueringsprosesser og kvalitetsvurderinger. ${ }^{9}$

I norsk sammenheng finnes det generelt lite forskning på kvalitetskriterier i tilsettingsprosesser og opprykk i vitenskapelige stillinger, selv om det er kjent at fagkulturer tolker og operasjonaliserer «Forskrift om ansettelse og opprykk i undervisnings- og forskerstillinger» ${ }^{10}$ forskjellig (Larsen, 2017). I studien Balansekunst i kunstfagene (Blix \& Mittner, 2018) viser en intervjuundersøkelse med ledere for utøvende musikkutdanninger i Norge at de er positive til moderat kjønnskvotering ved tilsettinger, men at det går en grense som handler om å ikke gå på akkord med kvalitet, samtidig som de sier at kvalitet er vanskelig å definere. Det er derfor behov for studier som undersøker hvordan kategorien kjønn påvirker diskursive praksiser rundt begrepet kvalitet (Mullany, 2012).

Når forståelser av kvalitet i kunstneriske fag skal overføres til akademiske sammenhenger, møtes to nokså forskjellige epistemologiske systemer (Gürgens, 2004, s. 150). Mens en i akademiske vurderingsprosesser legger vekt på å telle antall vitenskapelige artikler, er det sentralt i bedømmelser av kunstneriske vurderingsprosesser å vise til anerkjennelse og originalitet. Hva som konstituerer originalitet er likevel ofte uklart, nettopp fordi det nyskapende vektlegges. Mortensen (2015) uttrykker denne balansen mellom vage, uforutsigbare kriterier, og behovet for å kunne si noe mer konkret om kunstnerisk kvalitet slik:

Kunstnerisk kvalitet er aldri verken absolutt eller relativ, men rugger urolig mellom disse to posisjonene (...). Det er nettopp kvalitetsbegrepets nervøse rugging man ikke kan redusere til stabile størrelser (godt versus dårlig håndverk, f.eks.), men er nødt til å ta til etterretning, særlig fordi det ikke minst er akkurat denne ustabiliteten som konstant skaper ikke bare ny kunstkritikk, men også ny kunst (Mortensen, 2015, s. 2).

Hva som forventes i en søknad om opprykk i et utøvende kunstfag ved universiteter og høgskoler kan derfor framstå som noe diffust for søkeren når de leser forskriften. Kvalitet er aldri absolutt og må operasjonaliseres av aktørene kontekstuelt (Eliassen \& Prytz, 2016), og dette skjer i tilknytting til ulike underliggende diskurser (Mullany, 2007). Fortolkningen av forventningene kan derfor være en utfordring for søkeren, og kanskje spesielt for kvinner, som forskning viser har en tendens til å undervurdere egen kompetanse og status i søknadsprosesser (Beyer, 1990).

Makt, status, elitetenking og prestisje virker alltid inn på prosesser rundt kvalitetstilskriving (Abelsen, 2009; Ginsburgh, 2003; Stavrum, 2014). Blant annet derfor er anerkjennelse og synliggjøring viktig for kunstneres karriereutvikling (Blix, 2017; Heian, 2018). I denne artikkelen ser vi på aktører i kunstfeltet som refererer til forskjellige former for symbolsk makt (Bourdieu, 2007). Brink (2013) beskriver eksempelvis hvordan individuelle holdninger, smak, skjønn og organisatoriskstrukturelle rutiner styrer konkrete seleksjonsmekanismer. Selv om vurderingsprosessene er komplekse, tilskrives den enkelte aktøren i feltet makt gjennom uformelle portvokterfunksjoner.

Brandser \& Sümer (2016) refererer til måter organisatoriske prosesser kan ha forskjellig effekt på kvinner og menns karriereutvikling i akademia på. Kvinners karriereveier beskrives i noen sammenhenger som labyrinter med stadig nye blindveier (Eagly \& Carli, 2007). I tillegg er vektleggingen av fremragende kvalitet blitt sterkere vektlagt i akademia de seneste årene, blant annet gjennom sentre for fremragende forskning og EUs rammeprogram for forskning og innovasjon med sin vektlegging av «Excellent Science». Denne typen eksellenstenkning står også sterkt i estetiske

\footnotetext{
${ }^{9}$ Se mer om kjønn som performativt fenomen i Gjærum \& Aure, 2016, side 20: http://dramaogteater.no/wpcontent/uploads/2016/12/Drama 03 2016-web.pdf

${ }^{10}$ Paragraf $1.2 \mathrm{i}$ «Forskrift om ansettelse og opprykk i undervisnings- og forskerstillinger» url: (https://lovdata.no/dokument/SF/forskrift/2006-02-09-129) (hentet 23.8 2018).
} 
vurderingsprosesser (Rønning, 2012). Disse kan hindre både kvinner og andre som står utenfor det en kan omtale som det hvite maskuline hegemoniet, å nå toppstillinger i akademiske felt (Nielsen, 2016).

Mennesker er ubevisst forutinntatt, ikke bare når det gjelder kjønn, men også i prosesser knyttet til forskningsprosjekter, publikasjonsorganer, forskningsmetodikk eller fagfelt, noe som omtales som implicit bias (Holroyd et al., 2017). De nasjonale forskningsetiske komiteene peker på at:

Forskerens egne holdninger og bevissthet rundt muligheter for egen forutinntatthet og forskningsskjevheter er en viktig forutsetning for å redusere faren for bias samt å redusere eventuelle negative effekter som følge av forskningsbias. ${ }^{11}$

I begrepet kjønnsbias ligger det å være forutinntatt på grunn av kjønn, altså at holdninger preget av tradisjonelle kjønnsstereotyper kommer til utrykk i handlinger vi utfører eller utsagn vi fremmer, ofte ubevisst. Forskning som ser på kategoriene kjønn og kompetanse viser at kvinner og menns akademiske arbeid har en tendens til å vurderes forskjellig. For eksempel viste en amerikansk studie fra 2012 hvordan 127 professorer i fagene biologi, kjemi og fysikk vurderte hypotetiske søkere til en laboratorielederjobb forskjellig basert på kjønn. Professorene vurderte den fiktive søkeren John som klart bedre enn søkeren Jennifer, selv om søknadene ellers var identiske. (Moss-Racusin et al., 2012). Lignende eksempler på kjønnsbias ser en i studier av måten kvinners kompetanse og lederegenskaper vurderes annerledes enn menn, hvor «spisse albuer» er en positiv egenskap for menn, mens kvinner blir negativt vurdert hvis de viser til samme pågåenhet (Gaustad \& Raknes, 2015). I en svensk studie viste Wennerås og Wold at i konkurransen om postdoktorstillinger i biomedisin finansiert av Vetenskapsrådet, måtte kvinner publisere 2,5 ganger så mye forskning for å bli vurdert som like kompetente som de mannlige søkerne (Wennerås \& Wold, 1997). Kvinner i lederstillinger står oftere i fare for å bli negativt vurdert uansett om de velger å følge forventingene om feminin oppførsel (samarbeidsorientert), eller viser stor grad av konkurranseorientert væremåte (Lakoff, 2008; Mullany, 2007).

I sin undersøkelse av norske kunstneres lønnsvilkår, viser Heian (2018) til at det er mye større forskjeller på inntektene til mannlige og kvinnelige kunstnere enn i yrkesbefolkningen ellers, og at det kan se ut til at årsaken er en kombinasjon av en kjønnet arbeidsdeling og uformelle vurderingsprosesser preget av hegemoniske kvalitetsforståelser. Artikkelen konkluderer med at det er:

viktig å få mer systematisk kunnskap om hvilken type kompetanse som verdsettes hos kvinnelige versus mannlige kunstnere, i hvilken grad kompetansen brukes forskjellig, og hvilke mekanismer som gjør seg gjeldende for den kjønnede rekrutteringen til ulike stilarter, sjangre og posisjoner på kunstfeltet (Heian, 2018, s. 64).

\section{Forskningsmetode}

\section{Strategisk utvalg}

Den foreliggende studien ble igangsatt som en kvalitativ undersøkelse av kvalitetsvurdering i opprykksbedømmelser i 2015. Forskerne gjorde semistrukturerte dybdeintervjuer med fem strategisk utvalgte, erfarne medlemmer og ledere av vurderingskomiteer i kunstutdanningsfeltet (Kvale \& Brinckman, 2009). Det ble lagt vekt på et utvalg med geografisk og faglig spredning på tvers av kunstfagene musikk, drama/teater og visuell kunst. Disse fagene representerer relativt små fagmiljøer i akademia i Norge. Antall professorer/dosenter i de tre kunstfagene er derfor lavt sammenliknet med andre akademiske disipliner, og av den grunn vil mange av de samme professorene og dosentene måtte

\footnotetext{
${ }^{11}$ Hentet 01.02.2018 fra https://www.etikkom.no/fbib/temaer/spesielle-problemomrader/bias/.
} 
bidra ofte i komitéarbeid over mange år. Vi har valgt fem slike erfarne komitémedlemmer som informanter til vår studie.

Utvalget av informanter i studien består av fire professorer og en dosent med lang erfaring som medlemmer og ledere av sakkyndige komiteer. Informantene, tre kvinner og to menn i alderen 58-76, har vært fast ansatte ved forskjellige norske universiteter og høgskoler i en årrekke innenfor fagene musikk, drama/teater og visuell kunst. Siden fagene er små og preget av tette kjennskapsbånd, valgte vi av hensyn til anonymitet å ikke opplyse hvilke informanter som representerer de enkelte fagene. Informantene er gitt fiktive navn i artikkelen.

\section{Kvalitative forskningsintervju}

Informantene deltok i et ca. timelangt intervju som så ble transkribert. En felles intervjuguide med 26 spørsmål styrte samtalene, i tillegg til oppfølgingsspørsmål utledet av intervjusamtalene. Guiden strukturerte samtalene ut fra følgende hovedtemaer: kvalitet, kjønn, skjønn, komitéopplæring, utfordringer, samarbeid og nettverk. Informantene ble oppfordret til å fortelle om egne erfaringer med vurderingsprosesser. Informantene ble også bedt om å utrede hvorledes de forstår forskriftens formuleringer «høyeste nivå etter internasjonal standard» og «relevant bredde og fordypning på høyeste nivå». I tillegg ble de oppfordret til å kvantifisere og verbalt definere hvor mye kompetanse de mener er nok for å bli professor/dosent. Forskerne ba informantene om å reflektere rundt hvor stor innvirkning profileringsdokumentet/søknadsbrevet har på komiteens vurdering, eller om det er det innsendte kunstneriske materialet alene som blir bestemmende for vurderingen. Etter intervjuet sendte en del informanter inn kommentarer og tanker de hadde fătt i etterkant av intervjuet i form av e-post, $\mathrm{i}$ tillegg til en del dokumenter som utdypet deres utsagn. Dette materialet ble sett på som et supplement til intervjutranskripsjonene.

\section{Diskursanalyse}

Intervjutranskripsjonene ble lest og tolket av de tre forskerne hver for seg, og deretter diskutert i forskerteamet og videre tolket diskursanalytisk (Jørgensen \& Phillips, 2002). Vi anvender diskursbegrepet på argumenter, meninger og diskusjoner som alle kan spores til én stamme. Dermed kan en generere en selvstendig diskurs dersom den kan gjensidig utelukkes fra en annen diskurs. Forskerne ønsket ved bruk av datamaterialet å definere ulike diskurser på bakgrunn av utsagn fra den enkelte informant, for så å se om det var mulig å spore felles diskurser på tvers av informantutsagnene. Vi forstår diskursbegrepet i et Foucault-perspektiv (1970), og vi har anvendt det en kan definere som en genealogisk metode for å lete etter mønster, spor eller stier mellom fag, informanter og miljøer. « Genealogy looks for "emergence" rather than evolution ... for discontinuities, divergences and «marginal elements» in events and for the unstable assemblage of faults, fissures and heterogeneous layers. (Jackson, 2007, s. 10). Det diskursive universet til Foucault hjelper oss å forstå hvor og hvordan mening oppstår og utvikles (Jørgensen \& Phillips, 2002). Ved bruk av kritisk diskursanalyse ser vi ikke bare på kommunikative aspekter som språk, argumentasjon og eksempler, men også på den bredere konteksten diskursene utfolder seg i (Fairclough, 2012). På den måten synliggjøres maktkonstellasjoner og fagspesifikke verdisystemer som ligger implisitt i det som forhandles eksplisitt. Denne metodisk-teoretiske tilnærmingen innebærer at endringer i diskursiv praksis på sikt vil føre til endringer i sosiale omgivelser (Jørgensen \& Phillips, 2002), hvilket er beveggrunnen til at vår studie ble initiert og finansiert av Norges forskningsråd. 
Denne artikkelen er empirinær og fremviser intervjusitater fra intervjumaterialet som blir presentert i form av en diskursanalyse. Datamaterialet er i det følgende tematisk kategorisert og deretter analysert i forhold til tidligere forskning i feltet og sett i lys av teorier om kvalitet, diskurs og makt.

\section{Analyse og diskusjon av funn}

I denne analysen undersøker vi sentrale diskurser som kan identifiseres i komitémedlemmenes refleksjoner over vurderinger av toppkompetanse i kunstfagene. Diskursene fremkommer gjennom informantenes språkbruk og argumentasjon under intervjuene, og gjennom eksempler de velger å anvende i samtale med forskerne. Språklig ser vi diskursene komme til syne gjennom blant annet deres bruk av metaforer som for eksempel «høvdinger», «supermann», «dolledame», «pondus» og «tempelvoktere». I materialet utkrystalliserer det seg tre hoveddiskurser slik vi fortolker informantenes utsagn, og vi har kalt disse kvalitetsdiskursen, kjønnsdiskursen og elitediskursen.

\section{Kvalitetsdiskursen}

Alle informantene er svært engasjert i spørsmålet om hvordan kvalitet defineres i vurderinger av søknader om toppkompetanse på kunstnerisk grunnlag. En av informantene hevder at «kvalitetskortet» trumfer alle andre prioriteringer i kunstfagene som for eksempel flerkulturelt mangfold eller kjønnsbalanse, og derfor er denne diskursen svært viktig å definere klart. Med kvalitet mener informanten Caroline ${ }^{12}$ «in time on tune», mens Lise trekker frem viktigheten av at søkerens vedlagte materiale fremstår som «relevant og er en del av en faglig diskurs». Videre utdyper hun at «det er ikke snakk om kvalitet i entall, men om søkerens kvaliteter». God kvalitet innebærer også «tilstrekkelig dybde og bredde» ifølge informantene. Julian presiserer at det må formidles «fortellinger som går i dybden», mens «nyskapning - i sin kontekst» fremheves av Lise som et klart kriterium for kvalitet på toppnivå. Søkeren må også kunne dokumentere «høyt nivå og jevnlig aktivitet» og «kunne bidra internasjonalt, hvor som helst, med en verkshøyde» ifølge Sofie. Vurderingen av kvalitet og bredde henger sammen med kunstneriske valg, sjanger, stil og tradisjon, sier alle informantene. Innsikt i hva som er høy kvalitet er noe en opparbeider en intuitiv forståelse for gjennom et langt arbeidsliv og kunstnerskap: «jeg har liksom en fornemmelse av - det kan kanskje kalles gut-feeling på ... En kan si det er likes og dislikes da, men det er jo kriterier som komiteen anvender i sin vurdering», forteller Caroline. Dette utsagnet illustrerer måter diskursiv makt kan ligge i våre smaksdommer og kulturelle preferanser (Abelsen, 2009; Bourdieu, 1984; Ginsburgh, 2003). Petter uttaler at kvalitet er det han, med sin faglige ballast og erfaring, opplever som «bra, bra nok», mens Sofie sier at kvalitet på toppnivå må innebære å ha «gitt vesentlige bidrag til utviklingen av et felt». Vi ser her at komitémedlemmene definerer kvalitet ulikt selv om de alle forholder seg til samme forskrift. Dette er tankevekkende, og samtidig problematisk ifølge informantene.

Søknadenes vedlagte dokumentasjon av kunstnerisk virksomhet må ifølge informantene også inneha en viss teknisk kvalitet for å fremstå som troverdige: «kvaliteten på innspillingene - det skal ikke være for mange dårlige innspillinger for eksempel med mobiltelefon», sier Caroline. Julian uttaler at han alltid undersøker i det innsendte materialet om søkeren blir «jevnlig brukt i for eksempel Harlem, eller i London, eller har kurs rundt omkring. Hvis det ikke eksisterer noe sånt, så er jeg ofte veldig kritisk.» Informanten Caroline meddeler at hun «syns jo personlig at man skulle legge mer vekt

\footnotetext{
${ }^{12}$ Informantene er gitt fiktive navn.
} 
på pedagogiske resultater.» Vi ser altså spor av flere slike personlige kvalitetspreferanser hos alle informantene. Informantene forteller om at de på forskjellige måter operasjonaliserer kvalitetsbegrepene de anvender når de aktivt leter etter dokumentert «internasjonal erfaring» eller «konkret pedagogisk aktivitet i høyere utdanning», og når de forhandler diskursivt $\mathrm{i}$ komiteene om hva de mener er god nok kvalitet for å bli professor eller dosent. I datamaterialet ser vi at komitémedlemmene viser til utfordringer med fortolkninger av de formelle rammene for vurdering. Sofie er opptatt av at alle komiteer sliter noe med å tolke helheten i oppdraget de har fått. De må balansere betydningen av betenkningen, ${ }^{13}$ forskriften ${ }^{14}$, nasjonale, institusjonelle, lokale veiledninger. ${ }^{15}$ Hun forteller videre at hun derfor, sammen med andre komitémedlemmer, har laget en kriterieliste for en «dream candidate»:

1. Har god kunnskap om feltet.

2. Har høyt nivå på refleksjon på egen metode og estetikk.

3. Har en uttalt refleksjon om posisjonen han/hun søker til.

4. Har erfaring med praksis-basert forskning.

5. Har bred kunnskap om feltet han/hun skal inn i.

6. Har utviklet sin egen arbeidsmetode og ha internasjonal eller nasjonal pedagogisk erfaring».

Det er verdt å legge merke til at kvalitet på utøvende, kunstnerisk arbeid ikke nevnes direkte i denne listen over kriterier, et tema alle informantene er inne på flere ganger; vanskeligheten med å konkretisere kunstnerisk kvalitet.

Lise forteller i intervjuet at komitéarbeidet ikke er så utfordrende i felt en kjenner godt, fordi komitémedlemmer «utvikler litt sånn «nese» for hva som skal til» for å bli vurdert som professorkompetent. Caroline påpeker at en i komiteene likevel må diskutere, og bli enige om, fortolkningene av kvalitetsbegrepene som brukes, og at «høyeste nivå etter internasjonal standard ikke nødvendigvis betyr at man skal ha vært masse i utlandet. Men man skal ha spilt mye på det høye nivået som er fullstendig akseptabelt hvor som helst - også i utlandet». Petter påpeker at egen kulturbakgrunn skaper spesifikke kvalitetsforståelser som gjør at det å «lese ut» kunstnerisk kvalitet fra en kunstner fra en annen kultur, kan være vanskelig. Billedkunstneren Samir M'kadmi (2017) belyser fenomenet Petter omtaler, i essayet «Kunst eller estetikk - kvalitet gjennom smaksteori»:

Smakbedømming [er] bestemt av faktorer som ikke er en del av selve kunstobjektet. Faktorer som etnisitet, tradisjon, sosial bakgrunn, alder, utdanning, temperament og så videre påvirker vår smak og dermed måten vi vurderer kunstens produkter og kvalitet på. Bedømming av kunst har altså ikke bare en sanselig dimensjon, den har også en rekke andre bestemmende årsaker (Samir M'kadmi, 2017, s. 8).

Komitémedlemmene vi har intervjuet, bekrefter implisitt denne problemstillingen når de snakker om «fremmede kulturer», «tempelvoktere» eller «folkelig kunst». Lise trekker frem at hennes erfaring er at alle komiteer arbeider ganske ulikt, og dermed kan sammensetning av komiteen og komitémedlemmenes lojalitet, historikk og tilhørighet være av stor betydning for resultatet de kommer frem til. «Det er folk som har posisjoner, og så må du virkelig drive å forhandle fram og tilbake, og noen ganger så er det håpløst, og andre ganger er det mulig. Men det er alltid en eller annen sånn «tempelvokter» som sitter og ikke vil gi seg på visse ting». Vi ser i datamaterialet spor av det en kan

\footnotetext{
${ }^{13}$ Dette gjelder når en søker på en stilling. Ved opprykk brukes ikke stillingsbetenkninger direkte.

${ }^{14}$ Forskrift om ansettelse og opprykk i undervisnings- og forskerstillinger § 1-2 (2)

${ }^{15}$ F. eks: Nasjonalt fakultetsmøte for humanistiske fag, 2013
} 
kalle uryddig saksgang og partiskhet. Både Sofie og Petter deler fortellinger om komiteer som i stedet for å studere søkerens vedlagte arbeider grundig, tar snarveier som å google søkerens navn eller lytte til andre komitémedlemmers historier om søkeren. Petter forteller også om: «korrupsjon ja, det er jo maktmisbruk, totalt. Men det begrunnes med at institusjonene er autonome, og den autonomien er det ingen som tør å røre «Jo, og det er jo basert på at de ønsker seg én bestemt person». Informantene er svært klare på at slik adferd ikke er lov og at de arbeider i sine komiteer for å motvirke eller varsle når slikt forekommer. I datamaterialet finner vi omtalt én sak der komiteen ble meldt til institusjonen for dårlig arbeid, noe som resulterte $i$ at vurderingen ble trukket tilbake av ledelsen ved institusjonen.

Informantene er alle opptatt av at selve søknadsbrevet må være ryddig og preget av en realistisk selvfremstilling. Brevet, ofte omtalt som et profileringsdokument, må være «... ordentlig, kortfattet og to the point» (Caroline). Lise påpeker at «CV-en er vel så viktig. Den leses veldig nøye».

Informantene krever alle at en søker må være i stand til, også som kunstner, å reflektere godt skriftlig og presentere arbeidet sitt i en overbygning som kommuniserer arbeidenes betydning. «Så hvis ikke den refleksjonen, den skriftlige, den intellektuelle overbygningen er med og dokumentert hos søkeren, så mener jo jeg at det ikke er internasjonal kvalitet», hevder Julian. Måten søkeren har dokumentert sin faglige kvalitet på, viser seg altså å være av betydning for komiteens vurdering. Caroline understreker også at det ikke er uvesentlig hvordan brevet er skrevet fordi: «namedropping ikke kvalitativt er det samme som samarbeid med kjente utøvere». Vi ser på bakgrunn av datamaterialet at måten søkeren velger å verbalisere og presentere sine samarbeidskonstellasjoner kan ha stor betydning for vurderingen.

I analysen ser vi at det er enighet blant informantene om at kvalitet skal forstås i flertall. Studiens informanter definerer kvaliteter kontekstuelt og som både må fremskrives og dokumenteres som; relevant, aktuell, internasjonal og nyskapende. Kvalitetsmarkørene som anvendes av informantene er arena/scene, repertoarvalg, kontekstualisering, refleksjon og samarbeidsrelasjoner. Altså knyttes kvaliteter til hvor, hva og med hvem. Men kvalitetsdiskursen er preget av en ambivalens fordi informantene opplever å møte kolleger som tolker søkers kompetanse annerledes enn de giør selv. Petter forteller at: «Det er jo store personlige forskjeller på hvordan folk gjør denne [bedømmelses-] jobben. Alle ønsker å bevare sin faglige integritet og å ikke være usaklig». Særlig trekkes det frem at vektingen av pedagogiske kvalifikasjoner, definisjon av bredde og forståelse av internasjonal erfaring er ulik hos komitémedlemmer. Julian sier at: «Så hvis ikke den refleksjonen, og den skriftlige, den intellektuelle overbygningen er med og dokumentert hos søkeren, så mener jo jeg at det ikke er internasjonal kvalitet» Caroline vektlegger at: «Jeg syns jo personlig at man skulle legge mer vekt på pedagogiske resultater».

Informantene uttaler seg gjennom det en kan definere som et fortolkende repertoar «der angiver de måder hvorpå en kan tale om et givet fenomen» (Højgaard \& Søndergaard, 2003, s. 204). Her sees de tilgjengelige diskursene som rommer fenomenet «kvalitet» sin kulturelle historie. Derav kan vi forstå fenomenet $k v a l i t e t$ i kunstfagene som historisk fundert og preget av feltets hegemoniske kunstsyn, der kunstnerisk kvalitet knyttes til profesjonalitet, kunstnergeniet og den autonome kunstsfæren (Gürgens, 2004). Vi ser klart i materialet at diskursen er preget av en bevissthet rundt betydningen av komitémedlemmenes skjønn: «Det kan kanskje kalles gut-feeling på dette. En kan si det er likes og dislikes da, men det er kriterier» (Caroline). Kvalitetsdiskursen må dermed sies å være preget av en reproduksjon av gamle tankemønstre og en sementering av en elitistisk praksis (Solhjell \& Øien, 2012). 


\section{Elitediskursen}

Sofie er opptatt av å fortelle at komiteenes kunstsyn kan være preget av det hun velger å kalle: «Jåleri. Det gis cred for å jobbe på de store institusjonene, men ikke for å jobbe med mer folkelig kunst». Komiteens kunnskapssyn, smak og kulturell tilhørighet påvirker vurderingene som gjøres, forteller alle informantene. For eksempel sier én informant at: «Noen komponister rangeres høyere enn andre», noe forskriften ikke tar høyde for. Dette fenomenet, som vi ser spor av i flere deler av materialet, kan kalles «selvklassifiserende klassifiseringsakter» (Bourdieu, 1984). En hegner altså om egen kulturell smak ved å tale, agere og vurdere verden omkring seg ut fra egne «kulturelle briller», et fenomen en i kunstsosiologien og i estetikken lenge har vært opptatt av (Abelsen, 2009; Ginsburgh, 2003; Hegel, 1993).

Informantene diskuterer forholdet mellom kvalitet og prestisje på forskjellige måter. Det ligger ifølge én av informantene mer prestisje $\mathrm{i}$ å ha jobbet ved et institusjonsteater enn å jobbe med produksjon av folketeater: «Jeg tror at ... de [komiteen] betrakter folketeateret som et fagfeltsom ikke har noen form for status, og derfor ... på en eller annen måte så skal du ha mer cred for at du har jobbet innenfor institusjonene». For musikerne ligger det mest prestisje i å være en mye brukt, berømt utøver, eller ha vært solist i utlandet, gjerne på spesifikke scener. Dette inngår i en kunstnerdiskurs hvor utøverposisjonen står i høysetet (Mangset, 2004). Informantene i studien refererer til egne felts oppfattelse av hva som regnes som prestisjefylt, noe som varierer fra kunstfelt til kunstfelt.

Henningsen (2003) bruker begrepet prestisjehierarki for å beskrive hvordan fagfelt i akademia vektlegger de mest meritterende aktivitetene for de ansatte. Alle informantene i denne studien uttrykker skepsis til det de oppfatter som etablerte prestisjehierarkier og sier eksempelvis at de ønsker at også undervisningskompetanse og bredde i typer praksiser burde være meritterende for professor/dosentopprykk. Julian understreker eksempelvis at: «Det viktige er nivået på det kunstneriske som presteres. Og at undervisningen er god, også. Det er mange som er ubrukelige til å undervise» og Sofie sier: «Jeg er opptatt av en oppvurdering av undervisning, for jeg syns dette universitetssystemet hvor lærebøker, og det som har med undervisning å gjøre, ikke teller noen ting, er helt latterlig».

Et lignende aspekt ved prestisjeproblematikken som kommer fram av materialet, er statusen til dosentstillingen. Denne beskrives av et par av informantene som lavere i rang enn professoratet og mer som en «trøstepremie» til de som ikke helt når opp til professortittelen: «Det er helt sikkert for å fange opp de som ikke klarer professorkompetansen ... og derfor har forskriftene alle disse valgene på dosent, og som det er noen som har, men de kommer aldri til å kunne klare det øverste nivået. Du kommer til førsteamanuensisnivået og der blir du stående og stange. Du kommer ikke høyere, og så syns de at «ja, de burde få et eller annet», derfor har de lagt inn alle disse tingene» (Petter). På tross av at en formelt sett er på toppstillingsnivå i akademia både som dosent og professor, oppfattes dosentstillingen av våre informanter som et lavere nivå i et kunstfaglig prestisjehierarki.

Ifølge Henningsen (2003) er kvinnelige akademikere i mindre grad opptatt av å posisjonere seg i forhold til disse hierarkiene, og mer tilbøyelige til å jobbe mer tverrfaglig, mer anvendt og ha bredere nedslagsfelt i sine arbeider. Dette fører ifølge Petter og Sofie til at kvinner som søker opprykk bruker lengre tid på å samle nok produsert FoU-arbeid av den typen som oppfattes som meritterende av opprykks-komiteene.

I studien spør vi informantene om de har erfart at kjennskap til søkeren har betydning for vurderingen. I bedømmelser av kunstnere er kjendisfaktoren av betydning blant annet fordi et kjent navn gir prestisje for institusjonen. Informantene bekrefter at dette har betydning i vurderingene: «Det er uvanlig at ingen i komiteen har hørt om søkeren før, og i slike tilfeller føler vi oss nærmest 
inkompetente. Hvis vi ikke kjenner søkerens arbeider, så ser man jo kanskje etter nettverket rundt, så det er uvanlig at man ikke kjenner til dette» (Lise). Det å være kjent/berømt og være en del av et betydningsfullt nettverk har betydning for måten opprykkssøknader blir behandlet på (Proudfoot et al., 2015). Opprykksøkerne som streber etter å bli en del av eliten, beskrives av informantene gjennom en innenfor/utenfor-akse via romlige metaforer som «å komme seg innenfor», «å treffe blink», «å orientere seg i terrenget», «gli gjennom», «komme over streken», «å risikere å dras ned eller dras bort», «å holdes utenfor», «å være under vannlinja», «å være helt på jordet»og «å hoppe så vidt over kulen». Språket konstruerer subjektposisjonene, og diskursen om eliten i de omtalte kunstfeltene språksettes normativt gjennom informantenes metaforiske begrepsbruk når de viser til hvem som besitter makt i feltet.

Måten informantene uttaler seg om hva de mener bør vektlegges i kompetansevurderinger av professorer/dosent i kunstfagene, tyder på et kommende paradigmeskifte hvor pedagogiske meritter, et bredere kunstsyn og prestasjoner også utenfor de tradisjonelt prestisjefylte arenaene får større status. Dette ser vi blant annet ved NTNU og UiT sine nyopprettede pedagogiske meritteringsordninger som har som mål å øke statusen til pedagogisk kompetanse. De kvinnelige informantene artikulerer et ønske om større vektlegging av pedagogikk, folkekunst og en meritokratisk vurderingskultur i bedømmelsene av hva kvalitet i professor-/dosentopprykk er, noe de uttrykker at tempelvokterne ikke er opptatt av. Informantene i datamaterialet refererer flere ganger til kjønnsstereotypier som innebærer at menn betraktes som eliten, men viser samtidig til en skepsis til disse posisjonenes rettmessighet.

Elitediskursens representasjon i datamaterialet kommer altså til syne gjennom fortellinger om tempelvoktere, portvoktere, gutta boys, høvdinger, høye herrer og damer som «de andre» som vokter over hva som konstituerer kvalitet ut fra sine posisjoner. Informantene er samtidig selv voktere som uttaler seg fra sine maktposisjoner, og representerer forvaltere av kulturen som de tidvis uttrykker skepsis overfor. De problematiserer likevel ikke sine egne roller som subjekter i sammenheng med bedømmelsesarbeid i særlig grad.

\section{Kjønnsdiskursen}

Enkelte komitémedlemmer har opplevd kjønn som betydningsfullt i vurderingsprosesser, mens andre hevder at kjønn ikke spiller en rolle. Interessant nok refererer alle til kjønnsforskjeller mellom kvinner og menn og hvordan disse påvirker konkrete handlinger, måter å snakke og måter å ta avgjørelser på. På et overordnet plan tyder materialet på at kategorien kjønn påvirker komitémedlemmenes arbeid i relativt stor grad.

Kjønn har ikke eksplisitt blitt diskutert i komitéarbeidene informantene har deltatt i, og flere av dem opplever dette som en mangel $i$ arbeidet. Sofie sier at når institusjonen giør sine vurderinger «kommer man jo inn på dette med personlige egenskaper, og da er jo kjønn en del av det». Denne uttalelsen tyder på at det gjøres en indirekte kobling mellom kjønn og personlige egenskaper. Sofie trekker også fram at hun som kvinne ofte får eller tar jobben som advokat for de kvinnelige søkerne: «Hvis ikke jeg hadde sittet i de kommisjonene, så hadde de kvinnelige søkerne havnet ufattelig mye lengre ned på lista enn det de har gjort. Så jeg har vært veldig kjønnsbevisst». Dette kan tolkes dithen at hun anser det som nødvendig å ha ekstra fokus på kvinnelige søkere, fordi de ellers kan bli oversett. I den grad forutinntatthet tas inn i komitéarbeidet, er det knyttet til hvorvidt en kjenner til søkeren fra før. Dette er en problemstilling som indirekte kan knyttes til kjønn ettersom kvinnelige utøvere sjeldnere tilkjennes status som talenter eller kunstnergenier (Proudfoot et al., 2015). 
En av de mannlige informantene kommer inn på en opplevelse han har hatt i en komité, hvor han reagerte på måten en kvinnelig søker ble karakterisert på: «Hvis en mann bruker albuer så er det liksom korrekt, og det gjør man, men hvis et kvinnfolk gjør det, så er hun farlig, for da er hun sterk. Det var jo ikke slik de sa det i komiteen, men det er jo det som er realiteten. En skal ikke ha sterk personlighet hvis man er dame» (Julian). Bak utsagnet kan en spore en formening om at dette er en nokså vanlig holdning til sterke kvinner, og noe som informanten finner svært kritikkverdig. Caroline uttrykker en ambivalens knyttet til det å bruke det at en er kvinne som brekkstang for å få jobber: «Det er jo mange kvinner nå for tiden som er veldig kjent, og som bruker kjønnet for det det er verd. Med å dresse seg opp og dolle seg til» (Caroline). På den andre siden innrømmer Caroline at hun har fått en del sjanser som utøver nettopp fordi hun er én av svært få kvinner i sitt felt.

Alle informantene sier at kvinner venter lenger med å sende inn søknader om opprykk, og at dette i hovedsak er basert på at kvinner ofte ønsker å være sikre på at søknaden holder mål. Forskjellen på kvinner og menn blir i datamaterialet i denne studien beskrevet som en konkret forskjell på hvor selvkritiske og selvsikre en er: «Kvinner er ikke selvframskrivende på samme måte», sier Sofie. «Kvinner undervurderer seg selv alt for mye. Når de først søker, så er det ikke sånn at de bare «subber over kulen», men da hopper de langt ned i bakken», forteller Petter. «Kvinnene er litt mer ... selvkritiske, og for å komme med det man har, er tvilen litt større av og til» legger Caroline til. «Hvis du ser i mitt fagmiljø, så vet mennene fra dag én hvilken vei pilen peker. Mennene er veldig karrierebevisste, og i det øyeblikket de er en millimeter innenfor, så søker de» (Sofie). «Det er jo noen jeg har vurdert faktisk tre ganger, og det er jo da selvfølgelig menn, ikke sant. Og vi har ikke hatt noen avslag på kvinner som har søkt....Gutta tar det mer som det kommer», forteller Petter.

Alle disse utsagnene stemmer overens med forskning som peker på at menn i større grad tar sjanser og er mer karrierebevisste (Kyvik et al., 2003). I tillegg nevnes det av våre informanter at kvinnelige komitémedlemmer ofte er bedre forberedt til komitéarbeidet, noe som også kan henge sammen med en opplevd tendens til at kvinner er mer samvittighetsfulle når det gjelder andre typer arbeid i institusjonene enn det rent karrierefremmende. Informantenes utsagn harmonerer også med nyere studier som viser at arbeidsfordelingen i akademia er kjønnet på bekostning av kvinners karrieremuligheter (Ahlqvist et al., 2013). En av informantene beskriver kjønnsforskjeller i måten komitémedlemmene jobber på slik:

Kvinnene er jo mye greiere å jobbe sammen med. Men, altså, det er helt sant. Der er det jo aldri noe tull. Menn kan bruke mer sånn skippertaksmetode. Mens kvinner bruker veldig mye tid, og det sitter forferdelig langt inne å komme med noen konklusjon, og krabber litt sånn sidelengs når det begynner å nærme seg slutten, er det mye lettere med menn (Petter).

Vi ser her hvordan Petter er litt ambivalent i forhold til mannlige og kvinnelige komitémedlemmer, og trekker frem det han oppfatter som kjønnede handlingsmønstre ved sine komitékolleger.

Et par av informantene, begge kvinner, nevner omsorgsarbeid som en forklaring på kjønnsubalansen i kunstfeltet: «Familieansvar hemmer karriereutvikling til kvinner blant annet fordi de følger sine menn i deres karrierer eller må ta pauser i egen karriere på grunn av at de ønsker å ta ansvaret for barn» sier Caroline. «Når jeg gikk på [skole for utøvende kunstnere] og ble gravid så fikk jeg høre at jeg kunne jo ikke bli gravid hvis jeg hadde tenkt å bli kunstner. Det går ikke.», minnes Sofie. Dette kan tolkes som en bruk av patriarkalsk makt, ordsatt på en slik måte at kvinnene blir stengt ute av arbeidslivet fordi de er «annerledes» skapt enn menn.

De fem informantene i studien understreker alle at det vanligvis er få kvinner i komiteene de har sittet i. De tre kvinnelige informantene sier at de sjelden eller aldri har sittet sammen med andre 
kvinner i opprykks- og tilsettingskomiteer. Komiteer som vurderer opprykk i akademia skal bestå av minst én av hvert kjønn, og informantenes erfaringer sannsynliggjør at den lovpålagte kjønnsbalansen vektlegges ulikt av institusjonene for å sikre kjønnsbalanse. Når vi spør informantene hvilken rolle kjønn spiller for kvalitetsbedømmelser i kunstfeltet, svarer de at det ikke burde ha noen betydning, men at det viser seg å ha det likevel:

Du kan jo bare se på hele bildet, så er det jo klart at kjønn er betydningsfullt. Selv om vi har tiltak som likestillingsrådgiver og mentorordninger. Det gjøres ting hele tiden, men statistikken peker jo feil. Det er jo i vårt fagfelt nesten bare kvinner, bortsett fra professorene som er omtrent bare menn (Sofie).

Informanten Sofie påpeker at hele hennes arbeidsliv har vært preget av at kjønn har betydning for hvem som sitter med definisjonsmakten, hvem portvokterne er, og hvem som får opprykk. Flere av våre informanter referere til en form for portvoktere i feltet.

Og så er det selvfølgelig, som vi har vært inne på, når det gjelder vitenskapelige stillinger, så er det masse dritt og møkk som kommer. Da er det folk som har posisjoner og ... så du må virkelig drive å forhandle fram og tilbake og noen ganger så er det håpløst, og andre ganger er det mulig. Men det er alltid en eller annen sånn «tempelvokter» som sitter og ikke vil gi seg på visse ting (Lise).

Julian er også opptatt av portvoktere, men bruker begrepet «høvdinger» som «kommuniserer kun til seg selv», og Caroline referer til «de høye herrer eller damer». I dette ligger det en antakelse om at enkeltindivider vurderer kunstnerisk kvalitet basert på egne smaksdommer og «estetisk velbehag» (Danielsen, 2016, s. 114).

Datamaterialet viser at det finnes primært to måter å problematisere kjønn på i sammenheng med komitéarbeidet. På den ene siden oppleves kvinner som et «problem» og at de må «løftes frem». De er «i større grad uvillige til å ta ansvar», men «undervurderer seg alt for mye». Informantene beskriver kvinnene som enten «ikke god nok» eller «altfor god» (Crawford, 1995; Lakoff, 2008; Mullany, 2007). På den andre siden viser materialet at også menn kan oppleves som problematiske. De sitter som «høvdinger» i sin «mannsbastion», «bruker albuer» og «tviler for lite». Denne måten å skille mellom kvinner og menn på, beskrives i forskning som «discourse of gender difference» (Mullany, 2012, s. 513). Dette samsvarer med forståelser av kjønnsforskjeller i både sosiokulturelle og biologiske forklaringsmodeller (Ryle, 2015). Måten informantene uttaler seg på i vårt materiale, viser at det mangler et mer presist, ikke-metaforisk begrepsapparat rundt hvilken rolle kjønn spiller i forhold til kvalitet og eksellenstenkning.

\section{I kjønneste orden?}

Vi har undersøkt hvordan kvalitet blir forstått og forvaltet i vurdering av professor-/dosentkompetanse i høyere kunstutdanninger, og hvorvidt og på hvilke måter komitémedlemmene mener at kjønn har betydning for måten kvalitet vurderes på, og hvordan dette kommer til uttrykk.

Studien viser at komitémedlemmene operasjonaliserer sin kvalitetsforståelse med utgangspunkt i markører som arena, publikumstype, nytenkning, samarbeidsrelasjoner og egenart. Samtidig hevder informantene at kvalitetskriteriene i forskriften er for uklare. Disse vage kriteriene for opprykk sammen med et dominerende elitistisk kunstsyn i kunstutdanningsfeltet, fører ifølge informantene til at de som allerede har definisjonsmakt fortsetter å forvalte en rådende definisjon på kvalitet. Vi ser at det er en sammenheng mellom forståelser av kvalitet, en form for elitisme, og kjønn. Dette forsterkes av stadige forhandlinger i feltet om hva en mener kan gjøres eksplisitt og hva som regnes som ikke definerbare kvaliteter. De forskjelligartede kvalitetsforståelsene og ugjennomsiktigheten har en 
kjønnet dimensjon. Komitémedlemmene mener at kjønn har betydning både for måten en bedømmer kvalitet på og måten en fremskriver kvalitet i egen søknad. På bakgrunn av resultatene fra studien mener vi det er et behov for tydeligere og mer artikulerte kriterier i forskriften for hva som konstituerer kvalitet i utøvende kunst på professor-/dosentnivå i Norge.

Mangelen på språk om kunstnerisk kvalitet, og vanskene med å konkretisere bedømmelsesgrunnlagene, er faktorer som kan skape barrierer for kvinner, som i stor grad vurderes i og av mannsdominerte vurderingsinstanser (June, 2016; Sanders et al., 2011). Studien viser at det kan ligge usynlige barrierer for kvinner i vurderingsprosessene for toppstillinger, spesielt hvis kvalitetsdiskurser får hegemoni gjennom aksept av tatt-for-gitte praksiser i feltet. Materialet viser også tendenser til motdiskurser som både utfordrer hegemoniet og samtidig tydeliggjør den dominerende diskursen. Eksempelvis nevnes pedagogiske meritter, et bredere kunstsyn og nye faglige nettverk, noe som antyder et skifte i synet på hva som er kvalitet.

Flere av informantene uttrykker at de vet hva god kvalitet er når de ser det. Dette signaliserer at de mener det ikke alltid er nødvendig å beskrive konkrete kunstneriske kvalitetsmarkører, fordi det er tilstrekkelig at en gjennom sin posisjon som professor/dosent på feltet har den autoriteten og kunnskapen som skal til for å avgjøre hva som er av høy kvalitativt. Samtidig er informantene opptatt av tydeligere kriterier for kvalitetsvurderinger i opprykksbedømmelser. Det er verd å merke seg at de da ikke refererer spesifikt til den utøvende delen av virket til søkerne, altså kunstutøvelsens kvalitet, men til god pedagogikk, faglig bredde og evne til refleksjon. Det er derfor interessant at komitémedlemmene har vanskelig for å konkretisere kvalitetskriterier for selve det kunstneriske arbeidet, og samtidig er det i tilknytning til vurderinger av denne delen av søkernes kompetanse at elitisme og hegemoni får spillerom.

Informantene refererer på forskjellige måter til en kultur for elitetenkning som de er skeptiske til samtidig som de er en del av denne kulturen. Utsagnene kan tyde på at det er vanskelig å kritisere og debattere noe som ikke er klart definert. At kvalitetskriteriene i kunstfeltet er uartikulerte og dermed vanskelig å angripe, kan føre til at elitetenkningen framstår som enda mer hegemonisk. Eliten beskrives som hierarkisk både når det gjelder hva som gir prestisje, hvilke steder som er mest prestisjefylte, og hvem som representerer eliten i fagene. Kvalitet vurderes altså ut fra markører som sted/arena, publikumstype, nytenkning, samarbeidsrelasjoner og verkshøyde. Datamaterialet viser at det er relativt liten oppmerksomhet om at kjønnsubalansen skulle dreie seg om institusjonelle strukturer og at organisasjonskulturer kan være årsaken til vedvarende kjønnsubalanse på toppstillingsnivå. Informantene viser i liten grad til problemer som manglende transparens i søknadsprosesser, faghistorikk basert på maskuline premisser, eller reformer i sektoren som innebærer andre typer utfordringer for kvinner enn for menn (Brandser \& Sümer, 2016). Internasjonal forskning på kjønnsbalanse i akademia har derimot vist at det er nødvendig å fokusere på underliggende kulturelle og systemrelaterte faktorer som kan ha betydning for ubalansen på toppstillingsnivå (Nielsen, 2016, Højgaard \& Søndergaard, 2003).

Spørsmålet er hvordan en i akademia kan bidra til et mer demokratisk kunnskapshierarki som gir større bredde i hvem som opplever seg som aktuell som toppkompetent i akademia. I datamaterialet sporer vi et behov for et mer konkret vurderingsrammeverk med ferdige operasjonaliserbare kvalitetsvariabler. Med et nytt rammeverk, i betydning en revidert forskrift med tydeligere kvalitetskriterier, kan søkere i større grad vite $f ø r$ de søker hva som mer konkret kreves for å lykkes med en opprykksøknad. Det vil med en mer konkret forskrift heller ikke på samme måte være mulig for komiteer å la egne smaksdommer, personlig skjønn og kulturelle preferanser bli styrende i vurderingene. En implikasjon av studien er at det bør utarbeides en ny og forbedret forskrift som for 
eksempel angir hva som menes med «relevant bredde og fordypning» eller «vitenskapelig nivå i samsvar med internasjonal standard». Det er uheldig hvis disse framstår som diffuse både for potensielle søkere og bedømmelseskomiteer, spesielt fordi det kan bidra til å vedlikeholde kjønnsubalansen i akademia. Søkere har for eksempel behov for å vite hvor mange (og hva slags) artikler, konserter eller forestillinger som må framlegges for å kunne bli vurdert som toppkompetent $\mathrm{i}$ faget. Den ustrakte praksisen ved en rekke universiteter i Norge med fagspesifikke utdypinger av forskriften viser at fagmiljøene allerede ser behovet for slike konkretiseringer. ${ }^{16}$ Vi ser også et behov for nasjonale arenaer for kritiske drøftinger av hva kompetansemessig kvalitet i kunstutdanningsfeltet er, og hvorvidt det er tilstrekkelig at «høvdingene» i feltet har en «gut-feeling» for hva som er kvalitativt godt nok.

\section{Forfatteromtaler}

Hilde Synnøve Blix er professor i hørelære og musikkdidaktikk og ansatt på Musikkonservatoriet ved UiT - Norges arktiske universitet. Hun er utdannet musikkviter fra NTNU før hun tok sin Ph.D. i musikkpedagogikk ved Norges musikkhøgskole. Hennes forskningsinteresser er knyttet til gehørutvikling, notelesing og læremidler. I tillegg har hun de seneste årene forsket på likestilling og kjønn i musikkfeltet. Hun var i 2006 redaktør for boka Øre for musikk, og har senere publisert en rekke forskningsartikler og bøker nasjonalt og internasjonalt med tematikk som spenner fra gehørundervisning og notedidaktikk til likestilling og kunstnerisk utviklingsarbeid.

Lilli Mittner er postdoc ved Senter for kvinne- og kjønnsforskning ved UiT - Norges arktiske universitet. Hun er knyttet til tiltaks- og forskningsprosjektet «Prestisje: Kjønnsbalanse i forskningsledelse ved UiT - Norges arktiske universitet» og har tidligere vært prosjektkoordinator i BALANSE-prosjektet «Kjønn og skjønn» (NFR 2015-2018). Mittner arbeider stort sett interdisiplinært med fokus på hvordan humaniora kan bidra til å møte større samfunnsutfordringer knyttet til kjønn, alder og etnisitet. Hun er spesielt interessert i utforskning av co-kreative prosesser, samhandling, relasjonell estetikk og sosial rettferdighet. Mittner har faglig bakgrunn i musikkvitenskap og media- og kommunikasjon fra Universitet i Göttingen, Universitetet i Oslo og har en PhD fra Hochschule für Musik, Theater und Medien Hannover.

Rikke Gürgens Gjærum er leder for Arktisk senter for velferds- og funksjonshemmingsforskning ved UiT - Norges arktiske universitet, er professor drama/teater ved OsloMet. Har en doktorgrad fra NTNU i 2004, hovedfag i teatervitenskap v/UiO i 1998, allmennlærer og dramapedagog fra UiS. Hun arbeider med forskning på marginalisering og utenforskap, innovativ forskningsmetodikk, anvendt teater, disability art, reminisensteater, estetikkfilosofi og kunstbaserte medforskningsmetoder, men også med teaterkritikk og ulike anvendte antistigmatiserende teaterprosjekter i gruppen «Usedvanlig teater». Gjærum har skrevet en rekke forskningsartikler og bøker i løpet av 20 år i akademia.

\section{Referanser}

Abelsen, M. (2009). Kvinnelige kunstneres symbolske kapital - Om kunstinstitusjonens ideologiske maktstruktur. (Mastergradsavhandling). NTNU, Trondheim.

Ahlqvist, V., Andersson, J., Berg, C. H., Kolm, C., Söderqvist, L. \& Tumpane, J. (2013).

Jämställdhetsobservationer i ett urval av vetenskapsrådets beredningsgrupper. Stockholm: Vetenskapsrådet.

\footnotetext{
${ }^{16} \mathrm{~F}$. eks. nasjonale normer for professorkompetanse ved de medisinske fakultetene i Norge: http://ekstern.filer.uib.no/mofa/Ingrid $\% 20-\% 20$ diverse $/ 3 . \% 20$ Nasjonale $\% 20$ normer $\% 20 \mathrm{i} \% 20$ medisin.pdf (hentet 05.05.2019)
} 
Beyer, S. (1990). Gender differences in the accuracy of self-evaluations of performance. Journal of Personality and Social Psychology, 59, 960-970.

Biggs, M. \& Karlsson, H. (2010). Evaluating Quality in Artistic Research. The Routledge Companion to Research in the Arts, 405-424.

Blix, H. S. (2017). Framsnakk som likestillingstiltak. Kilden. Hentet 03.082018 fra http://kjonnsforskning.no/nb/2017/01/framsnakk-som-likestillingstiltak

Blix, H. S. \& Mittner, L. (2018). Balansekunst i utøvende musikkutdanning. En empirisk undersøkelse av lederes synspunkter på kjønnsbalanse og likestillingsarbeid ved de utøvende musikkutdanningene i Norge. Tidsskrift for kjønnsforskning 01-02/2018 (Vol. 42), 104119. 10.18261/issn.1891-1781-2018-01-02-07

Bourdieu, P. (1984). Distinction: a social critique of the judgement of taste. London: Routledge \& Kegan Paul.

Bourdieu, P. (2007). Den maskuline dominans (2. utg). Viborg: Tiderne Skifter.

Brandser, G. \& Sümer, S. (2016). Farefull ferd mot toppen. Kjønnsbalanse i forskning og forskningsledelse ved forsknings og utdanningsinstitusjoner i Bergen. Stein Rokkan senter for flerfaglige samfunnsstudier.

Brink M. van den (2013). Gender in Academic Networking: The Role of Gatekeepers in Professional Recruitment. Journal of Management Studies, 51(3), 460-492. https://doi.org/10.1111/joms.12060

Butler, J. (1990). Gender trouble: feminism and the subversion of identity. New York: Routledge.

Crawford, M. (1995). Talking difference: on gender and language. London: Thousand Oaks, Calif: SAGE.

Danielsen, A. (2016). Nyskapende, sterkt og kompetent!: Kvalitetsforståelser i musikkfeltet i lys av tre populærmusikalske sjangre. I K. O. Eliassen \& Ø. Prytz (red.), Kvalitetsforståelser. Kvalitetsbegrepet i samtidens kunst og kultur (s. 104-119). Oslo: Fagbokforlaget.

Eagly, A. H. \& Carli, L. L. (2007). Through the labyrinth: the truth about how women become leaders. Boston, Mass.: Harvard Business School Press.

Eliassen, K. O. \& Prytz, Ø. (red.). (2016). Kvalitetsforståelser: kvalitetsbegrepet i samtidens kunst og kultur. Oslo: Fagbokforlaget.

Fairclough, N. (2012). Critical discourse analysis. I J. P. Gee \& M. Handford (red.), The Routledge Handbook of Discourse Analysis (s. 9-20). Hoboken: Taylor and Francis.

Foucault, M. (1970). The order of things: an archaeology of the human sciences. London: Tavistock Publications.

Gaustad, T. \& Raknes, K. (2015). Menn som ikke liker karrierekvinner. Hovedresultater fra en eksperimentell undersøkelse. Rapport, Agenda. Hentet 05.05.2019 fra https://www.tankesmienagenda.no/wp-content/uploads/Tankesmien-Agenda-Rapport-Menn-som-ikke-likerkarrierekvinner.pdf

Ginsburgh, V. (2003). Awards, Success and Aesthetic Quality in the Arts. The Journal of Economic Perspectives, 17(2), 99-111. https://doi.org/10.1257/089533003765888458

Gjærum, R. G., Vollan, I., \& Bjerkestrand, K. B. (2015). Levd skuespillerliv og rolletildeling. En studie av kvinner i norsk institusjonsteater. InFormation - Nordic Journal of Art and Research, 4(2), 1-15. https://doi.org/10.7577/if.v4i2.1548

Gjærum, R. G. \& Aure, V. (2016). Kjønn som væren. Drama, 53(3), 20-29.

Gunnes, H. \& Olsen, B. M. (2016). Kvinner i kunstfagene. Oslo: NIFU.

Gunnes, H. \& Olsen, B. M. (2018). Statistikk om kvinner i kunstfagene 2009-2017 (NIFUArbeidsnotat 20. desember 2018).

http://kunstfak.no/wpcontent/uploads/2019/05/NIFU_2018_Oppdatert_statistikk_om_kvinner_i_kunstfagene.pdf

Gürgens, R. (2004) En usedvanlig estetikk, Trondheim: NTNU.

Hegel, G. (1993). Introductory Lectures on Aesthetics. (B. Bosanquet, Trans.) (Reprint edition). London: Penguin Classics.

Heian, M. T. (2018). Norske kunstnere og det doble likestillingsparadokset. Tidsskrift for kjønnsforskning 01-02/2018 (Vol. 42), 47-66. 10.18261/issn.1891-1781-2018-01-02-04

Henningsen, I. (2003): Modselektion eller efterslæb. I L. Højgaard og D. M. Søndergaard (red.) Akademisk tilblivelse. Akademia og dets kønnede befolkning. København: Akademisk forlag. 
Holroyd, J., Scaife, R., \& Stafford, T. (2017). Responsibility for implicit bias. Philosophy Compass, 12(3). https://doi.org/10.1111/phc3.12410

Højgaard, L. \& Søndergaard, D. M. (red.) (2003). Akademisk tilblivelse. Akademia og dens kønnede befolkning. København: Akademisk Forlag.

Jackson, A. (2007). Theatre, education and the making of meanings: art or instrument? Manchester: Manchester University Press.

June, A. W. (2016). The Uncertain Path to Full Professor. The Chronicle of Higher Education. Hentet fra https://www.chronicle.com/article/The-Uncertain-Path-to-Full/235304

Jørgensen, M. \& Phillips, L. (2002). Discourse Analysis as Theory and Method. London: Sage Publications.

Kvale, S. \& Brinkmann, S. (2009) Det kvalitative forskningsintervjuet. 2. utg. Oslo: Gyldendal.

Kyvik, S., Olsen, T. B. \& Hovdhaugen, E. (2003). Opprykk til professor. Kompetanse eller konkurranse? Oslo: NIFU STEP.

Lakoff, R. (2008). Language, Gender, and Politics: Putting "Women" and "Power" in the Same Sentence. I J. Holmes \& M. Meyerhoff (red.), The Handbook of Language and Gender (s. 160178).

Larsen, T. H. (2017). Frykter ulik behandling av universitetssøknader. Hentet 04.082018 fra http://www.khrono.no/soknad-universitet-hsn/frykter-ulik-behandling-avuniversitetssoknader/136734

Lund, C., Mangset, P. \& Aamodt, A. (red.). (2001). Kunst, kvalitet og politikk: rapport fra Norsk kulturråds årskonferanse 2000 (Vol. 22).

Mangset, P. (2004). "Mange er kalt, men få er utvalgt": kunstnerroller i endring (Rapport). Telemarksforsking Bø. Hentet 01.02.2018 fra https://teora.hit.no/handle/2282/494

M'kadmi, S. (2017). Kunst eller estetikk kvalitet gjennom smaksteori. Kulturrådet. Hentet 03.08.2018 fra http://www.kulturradet.no/fou/vis-artikkel/-/kunst-eller-estetikk-kvalitet-gjennom-smaksteori

Mortensen, A. (2015). Teser om kvalitet. Kulturrådet. Hentet 02.01.2019 fra http://www.kulturradet.no/kvalitet/vis/-/teser-om-kvalitet

Moss-Racusin, C. A., Dovidio, J. F., Brescoll, V. L., Graham, M. J. \& Handelsman, J. (2012). Science faculty's subtle gender biases favor male students. Proceedings of the National Academy of Sciences, 109(41), 16474-16479. https://doi.org/10.1073/pnas.1211286109

Mullany, L. (2007). Gendered discourse in the professional workplace. Basingstoke; New York: Palgrave Macmillan.

Mullany, L. (2012). Discourse, gender and professional communication. I J. P. Gee \& M. Handford (red.), The Routledge Handbook of Discourse Analysis (s. 509-522). London: Taylor and Francis.

Nasjonalt fakultetsmøte for humanistiske fag (2013). Veiledning for bedømming av søkere til professorater og professoropprykk. Hentet 03.04.2019 fra http://www.uhr.no/documents/Veiledning_professoropprykk_HUM_revidert.pdf

Nielsen, M. W. (2016). Scandinavian approaches to gender equality in academia: A comparative study. Scandinavian Journal of Educational Research, 1-24. https://doi.org/10.1080/00313831.2016.1147066

Nyamko, S. \& Twengström, K. (2009). På väg mot jämställd scenkonst. Stockholm: Statens kulturråd.

Proudfoot, D., Kay, A. C. \& Koval, C. Z. (2015). A gender Bias in the Attribution of Creativity: Archival and Experimental Evidence for the Perceived Association Between Masculinity and Creative Thinking. Psychological Science, 26(11), 1751-1761.

Rønning, A. B. (2012). Kunst, kjønn og estetisk vurdering. Tidsskrift for Kjønnsforskning, 36(01), $3-$ 17.

Ryle, R. (2015). Questioning gender: A sociological exploration. Thousand Oaks,CA: Pine Forge Press.

Sanders, M., Hrdlicka, J., Hellicar, M., Cottrell, D. \& Knox, J. (2011). What stops women from reaching the top? Confronting the tough issues - Gender parity study. Bain \& Company. Hentet $03.082018 \mathrm{fra}$ http://www.bain.com/publications/articles/what-stops-women-from-reaching-the-top.aspx

Solhjell, D. \& Øien, J. (2012). Det norske kunstfeltet: en sosiologisk innføring. Oslo: Universitetsforlaget.

Stavrum, H. (2014). Hvor mange gullplater henger på veggen? Om danseband og kvalitet. Sosiologi i dag, 44(1), 90-116. 
H. S. Blix, L. Mittner \& R. G. Gjærum: “I kjønneste orden?”

Wennerås, C. \& Wold, A. (1997). Nepotism and sexism in peer-review. Nature, 387(6631), 341-343. https://doi.org/10.1038/387341a0 